\title{
Breast Cancer Anti-Estrogen Resistance 3 Protein
}

National Cancer Institute

\section{Source}

National Cancer Institute. Breast Cancer Anti-Estrogen Resistance 3 Protein. NCI

Thesaurus. Code C21496.

Breast cancer anti-estrogen resistance protein 3 ( $825 \mathrm{aa}, \sim 93 \mathrm{kDa}$ ) is encoded by the human BCAR3 gene. This protein may be involved in receptor-mediated signaling. 